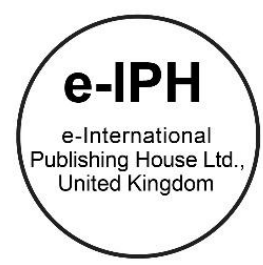

\title{
Fire Safety Management System for Heritage Buildings in Malaysia
}

\author{
Rozrinda Roslan ${ }^{1}$, Shahrul Yani Said ${ }^{2}$ \\ 1.2 Sustainable Heritage Environment Research Group, Faculty of Architecture, Planning and Surveying, \\ Universiti Teknologi MARA, Shah Alam 40000, Malaysia \\ rozrindaroslan@yahoo.com \\ $+60169230645$
}

\begin{abstract}
Fire is one of the horrific events that could lead to death and total destruction of buildings. Many great buildings were lost on fire. Many towns and cities were rebuilt because of great fires. Heritage buildings are recognized as over 50 years of age and built with distinct architectural features of its time. Nonetheless, these buildings present a great risk as it is often not well prepared for current fire hazard. This paper reviews the fire safety management system for heritage buildings in Malaysia based on selected research carried out.
\end{abstract}

Keywords: fire safety; heritage buildings; destruction by fire; fire management system

eISSN: 2398-4287@ 2017. The Authors. Published for AMER ABRA by e-International Publishing House, Ltd., UK. This is an open-access article under the CC BYNCND license (http://creativecommons.org/licenses/by-nc-nd/4.0/). Peer-review under responsibility of AMER (Association of Malaysian Environment-Behaviour Researchers), ABRA (Association of Behavioural Researchers on Asians) and cE-Bs (Centre for Environment-Behaviour Studies), Faculty of Architecture, Planning \& Surveying, Universiti Teknologi MARA, Malaysia.

https://doi.org/10.21834/e-bpj.v2i6.961

\subsection{Introduction}

Fire cause destruction of a building and its contents in only a few hours and its initial impact ls the potential loss of authenticity which is the most important of our cultural heritage flows and proved that it still the most significant threat (Kidd, 2003; Naziris, Lagaros, \& Papaioannou, 2016). Since heritage buildings were mostly built before the formulation of Uniform Building By-Laws 1984, hence the structures are not subjected to the provision of fire safety requirement which provided by the by-law.

However, the Fire-Rescue Department Malaysia (FRDM) requires these heritage buildings to be protected from the risks (Ibrahim, Ibrahim, et al., 2011). Fire prevention \& control system by Fire Rescue Department Malaysia states that protection in the aspects of fire prevention, control and extinguishment for a particular area based on the availability of risks in that area. It is a practice of mitigating the unwanted effects of fires.

Besides that, a fire safety system also includes the study of the behaviour, compartmentalisation, suppression and investigation of fire and its related emergencies. In protecting and preserving the historic fabric of the heritage structure, there are some significant differences which are a challenge for the architect and fire protection engineer in the application of general fire protection principles (Pickard, 1994). As according to Marchant (1989), the differences between historical and new buildings lie in the values attached to each of the components in each specific building context.

The challenge in protecting heritage structure is to maintain their historical fabric while providing a reasonable level of safety for their occupants and contents. To avoid harming the building's historic character, the architect and engineer will need to have the sensitivity and ingenuity approaches to provide fire prevention and protection measures. So that does not damage the historic fabric of the building since protecting our heritage is of prime importance not only for us but future generation as well (Akinciturk \& Kilic, 2004). According to Bailey (1993), each location should compile a fire safety manual setting out its strategy and detailing its plans in case of fire and as a basis for training. The site should also maintain a log book to record all fire-related events such as training, drills,

eISSN: 2398-4287@ 2017. The Authors. Published for AMER ABRA by e-International Publishing House, Ltd., UK. This is an open-access article under the CC BYNCND license (http://creativecommons.org/licenses/by-nc-nd/4.0/). Peer-review under responsibility of AMER (Association of Malaysian Environment-Behaviour Researchers), ABRA (Association of Behavioural Researchers on Asians) and cE-Bs (Centre for Environment-Behaviour Studies), Faculty of Architecture, Planning \& Surveying, Universiti Teknologi MARA, Malaysia.

https://doi.org/10.21834/e-bpj.v2i6.961 
inspections, and equipment maintenance. It is all referring to the overall plan preventive maintenance for fire safety in heritage buildings as to ensure when the fire occurs; and there are help and assistance for occupants (Meacham, 1999; Ramachandran, 1999).

\subsection{Aim of Study}

To review and analyse the current literature surrounding the topic of Fire Management System for Heritage Buildings in Malaysia especially on their findings

\subsection{Objectives of Study}

- To identify fire safety management condition at heritage buildings in Malaysia as had been assessed by other researchers.

- To analyse the fire safety criteria of heritage buildings assessed by other researchers relating to the literature review offered.

- To develop final finding and conclusion on the results by other researchers and literature reviewed.

\subsection{Significance of study}

Since fire is one of the threats that can affect the heritage buildings and might also ruin all the authenticity of the buildings, the fire safety management system seems to be so important in protecting it from any fire to occur. By assessing all the research on the fire safety management system at the selected heritage buildings in Malaysia, all the findings from these research could benefit all the stakeholder or management team of others heritage buildings. To manage the fire safety system, by the last developed finding and conclusion made at the end of this study.

Every each of the heritage buildings in Malaysia carries their characteristics that reflect the history of it and society surrounding. Therefore, as each of the parts of the heritage buildings needs to be protected, a very details action plan regarding on the fire safety management system should be implemented. The action plan should consider and prioritised both of people's lives and also the value of the building's part.

The implementation of a proper action plan regarding on the fire safety management system in the heritage buildings not only produce a high level of safety in order to avoid any fire to occur but also helps in reducing the maintenance or repair cost if there are fire event occur and ruin the buildings.

\subsection{Literature Review}

\subsection{Fire in Malaysia}

According to Salleh (2009), Fire and Rescue Department Malaysia reported that from 2005 to 2007 flame was brought on an aggregate loss of more than RM 2.4 billion that asserted 221 lives and harmed 268 individuals (Table 1), the most elevated aggregate passing and aggregate lost is recorded in the year 2007. Besides that, 3447 which is $17 \%$ from the total of 20225 fire cases in 2007 were involved in fire events; in fact, it was gradually increased from 2000 to 2007 and it is sure to keep rising until the present year. It has also been pointed out that several heritage buildings were severely damaged or burnt down in fire event which including People's Museum, Rumah Pak Ali and the Sarawak Club (Mydin, Sani, Abas, \& Khaw, 2014).

Table 1: Fire statistic in Malaysia for 2005-2007

Fire called $\quad$ Fire effect $\quad$ Loss (RM)

\begin{tabular}{lcccc} 
& & & & \\
\cline { 3 - 4 } & & Death & Injured & \\
$\mathbf{2 0 0 5}$ & 31138 & 70 & 115 & 794 million \\
$\mathbf{2 0 0 6}$ & 18913 & 71 & 86 & 760 million \\
$\mathbf{2 0 0 7}$ & 20225 & 80 & 67 & 865 million \\
TOTAL & 70276 & 221 & 268 & 2.4 Billion \\
\hline
\end{tabular}

(Source: Salleh, Fire safety in Heritage Buildings, 2009)

\subsection{Historic Buildings Fires in Malaysia}

In the context of historic buildings, until today, the fire caused damages and also destroyed many historic buildings in Malaysia which given a total loss approximately up to RM5 million (Salleh, 2009). It is believed that the main reason of this fire disaster in historic and heritage buildings is due to lack of fire safety awareness among the public and property owners are still at the unacceptable level. Hence, it will also result in an inferior standard of fire safety management and system in heritage buildings. As an example, according to Kidd (2003), in the past, many property owners who have undertaken fire protection improvement work in to obtain a Fire Certificate. But, most of them have not understood this, and in some cases, there has been confusion in respect of a fire authority's requirements as opposed to the advice by fire brigades or insurers.

\subsection{Fire Safety Management}

Fire safety management can be defined as the application by a manager of policy, standards, tools, information, and practices to the task of analyzing, evaluating and controlling fire safety. Fire is one of the disasters that might be causing deaths and casualties 
besides damage to property, the community, the economy, the environment and the most important part is to destroy the authenticity of the heritage buildings itself which is the most valuable part in the conservation of the heritage buildings itself. By inference, the management of the factors that can influence deaths, casualties, damage to property, destroy of authenticity etc, caused as a result of fire can be termed as fire safety management (Baker, Bouchlaghem, \& Emmitt, 2013; Marrion, 2016). As an example, there is research that made regarding on improving the fire safety of Italian- style historical theatres without altering their architectural characteristics. It is using an intelligent evacuation guidance, also adopts a "behavioural design" (BD) approach to increase individuals' safety (Bernardini, Azzolini, D'Orazio, \& Quagliarini, 2016).

An active fire safety management is a critical task in planning, designing, and operating a building. It is intended both to minimize the incidence of fire and to ensure that, when a fire does occur, appropriate fire system (including active, passive, and procedural systems) are in place and are fully functional (Baker et al., 2013; Wang, Barber, Johnson, \& Hui, 2013). As such a study on the fire protection of historic Cumalikizik village, North- West of Anatolia, the city of Bursa, Turkey by Akinciturk \& Kilic (2004), it is starting on developing concepts of fire safety planning, fire risk and present situation measures, and lastly developing the fire safety plan which include some elements that control or mitigate all fire hazards.

It is easy to achieve an adequate fire safety management for the new building since an architect would be able to assess at the early of the planning and design stage to identify whether the planned fire compartment, escape route and fire safety equipment meet regulations. But it is far bit difficult for heritage buildings since the assess took place at the post of the operation stage of the buildings. To resolve the issue, a study by Chen (2012), has made the perspective of hotel owners (operators) and considered the difficulty of construction and spatial improvements for buildings. Thus, without interrupting operations, a risk evaluation procedure, which would be a significant indicator of a fire management scheme for the hotel operators wanting to improve the safety level of their buildings, was established.

\subsection{Building Fire Safety and Heritage Building Legislation}

There is seven main legislation in Malaysia that may, directly and indirectly, relate to design and manage fire safety for heritage buildings in Malaysia. That legislation may divide in two key aspects which are building fire safety and heritage building (Table 2). Even though each of legislation may consist different scopes and requirements. However, in practice, they must be concurrently referred in order to ensure all the related legislation has been compiled at the satisfaction level.

Table 2: Legislation related to building fire safety and heritage buildings in Malaysia

\begin{tabular}{rlrl}
\hline Building Fire Safety & \multicolumn{2}{c}{ Heritage Building } \\
\hline 1) & Street, Drainage and Building Act 1974 (Act 133) & 1) & National Heritage Act 2005 (Act 645) \\
2) & Uniform Building By-Laws 1984 (UBBL 1984) - & 2) & Sarawak Cultural Heritage Ordinance (1993) - Sarawak Only \\
& Peninsular Malaysia \& Sabah & & \\
3) & Building Ordinance - Sarawak Only & \\
4) & Fire Services Act 1988 (Act 341) & \\
5) & Occupational Safety and Health Act 1994 (Act 514) &
\end{tabular}

(Source: Salleh, Fire safety in Heritage Buildings, 2009)

All of the above legislation highlighted the requirements related to the fire safety at the heritage buildings which differ to the common new buildings in Malaysia. As to fulfil the differences, Conseil International du Batiment (CIB) as an example, one of the international body been decided to set up a working group to prepare suitable recommendations which in order to assist authorities and experts in various countries faced with the issues of fire safety in historic or heritage buildings. It covers as many as possible of the different types of historic buildings, ancient monuments and buildings containing priceless items of national heritage and the guide used in conjunction with the national requirements for fire safety. The guidelines contain several parts including conservation issues, insurance aspects, categorization of buildings, fire experience, fire safety engineering, fire safety design, fire control issues, fire control issues, post-fire activities and also fire safety management.

\subsection{Fire Safety and Adaptive Reuse}

The careful and sympathetic design is needed to minimize the impact on the architectural and historic character of the buildings when fire precautions involving alterations to the building cannot be avoided and have those impacts. In some cases, a more satisfactory approach will be to avoid the circumstances that bring about the requirements for alterations. Most heritage authorities and organizations have accepted the principle that the best way to guarantee the future of a building is to keep it in use for its original purpose. Only where this is not possible will a change of use be considered and it is clear that significant strides have been made in finding appropriate alternative uses for many historic or heritage buildings. In all cases where a change of use of historic or heritage building is proposed, the planning authority should be contacted to see if Listed Building Consent and Planning Permission are required (Kidd, 2003).

\subsection{Research Methodology \& Limitation}

This paper reviewed research on fire safety management. A number of prominent research on fire management of historic buildings in Malaysia were selected and analysed to come out with the baseline data to support the theoretical framework of the overall research. 
The review of these researchers is very important for ongoing research in determining the variable or criteria that should be considered when involving fire safety for heritage buildings.

Comparative analysis carried out has highlighted main issue of fire safety management of heritage buildings in Malaysia. Nonetheless, the main limitation of this methodology is that review of other researchers are bounded and constraint by time. In order to facilitate and make do with the time constraints of the research, only several areas are focused. The literature review is located and obtained from major online databases such as IEEE, Emerald, and Scopus, which the selection of it been narrowed down to the keywords of either fire safety management, fire safety system and fire safety for Heritage Buildings.

\subsection{Findings}

Some of the research related to the fire safety for heritage buildings in Malaysia been reviewed in this study and Table 3 below shows the common acquisition from the findings of each research.

Table 3: List of research related to Fire Safety Management for Heritage Buildings in Malaysia

\begin{tabular}{|c|c|c|c|}
\hline \multirow[t]{2}{*}{ Author } & \multirow[t]{2}{*}{ Title } & \multicolumn{2}{|c|}{ Findings } \\
\hline & & $\begin{array}{l}\text { Poor Fire safety } \\
\text { Management } \\
\text { (Administration) }\end{array}$ & $\begin{array}{l}\text { Lack of Fire safety } \\
\text { Criteria (Building) }\end{array}$ \\
\hline (Salleh, Ahmad, 2009) & $\begin{array}{l}\text { Fire Safety Management in Heritage Buildings: The } \\
\text { Current Scenario in Malaysia }\end{array}$ & 1 & I \\
\hline $\begin{array}{l}\text { (Ibrahim, Abdul-Hamid, et al., } \\
\text { 2011) }\end{array}$ & $\begin{array}{l}\text { The Development of Fire Risk Assessment Method for } \\
\text { Heritage Building }\end{array}$ & & I \\
\hline (Ibrahim, Ibrahim, et al., 2011) & $\begin{array}{l}\text { Fire Risk Assessment of Heritage Building- Perspectives } \\
\text { of Regulatory Authority, Restorer and Building } \\
\text { Stakeholder }\end{array}$ & & 1 \\
\hline (Mydin et al., 2014) & $\begin{array}{l}\text { Evaluation of Fire Hazard and Safety Management of } \\
\text { Heritage Buildings in Georgetown, Penang }\end{array}$ & I & I \\
\hline (Mohamad, 2015) & $\begin{array}{l}\text { The Importance of Fire Safety in Historic Fire Safety in } \\
\text { Historic Buildings }\end{array}$ & 1 & 1 \\
\hline (Jamil, 2017) & Fire Safety Management in Heritage Buildings & I & I \\
\hline
\end{tabular}

From the literature reviewed stated that the fire safety management system is one of the important aspects that can help in contributing the sustainable conservation of the heritage buildings. It is not only protecting occupants of the buildings but also protects the material or valuable part of the heritage building which influenced the authenticity of it. But it is different from what is derived from the selected research, most of the administration of the heritage buildings in Malaysia still lack knowledge and awareness on the proper fire safety management for the heritage buildings.

According to Salleh (2009), out of 9 different states, 37 heritage buildings that previously or currently been adapted uses as museums having poor fire safety management and majority facing 17 leading problems such as administration of the buildings did not apply any fire safety plan into the buildings, they don't even have fire safety certificate and clearly not having direct link system to the nearest fire station which contributes major problem when in the event of fire. Besides, most of these researchers also highlighted that there is no competence person in charge to specifically handle health and safety issues as to guide the administration towards achieving a safe heritage building.

Mydin (2014) discusses the three selected case study which is Khoo Kongsi, Cheah Kongsi, Hock Teik Chen Shin Temple \& Teochew Temple, where the study show that the temple were mostly having the fire hazard that mainly comes from the joss sticks that been used for ancestral worship. Although the fire risks are moderate, obviously a lot more can be done to prevent the outbreak of fire in these buildings since they still not achieved a high level of fire risk protection awareness, by the guide of competence person in charge. All of the research also highlighted the lack of effective training related to the fire safety between staff and occupants of the selected case study which may also lead to failure to operate any fire extinguishers or to evacuate during fire events.

Fire safety in the buildings also influenced by others criteria which involving the building itself. As been assessed by Ibrahim et al (2011), by evaluating opinions from an expert such as BOMBA, contractor and maintenance personnel, the main fire safety criteria is passive and active protection system, fire management and also building characteristics which also supported by the theoretical statement in literature reviews. However, through another research those were made at the selected cases study as above, all of them still lacking these main fire safety criteria especially improper of installation of fire system and fire exit signage or escape route not exhibited in the buildings. At the end of this paper, hypotheses that were derived from all of the common acquisition from the research which actually the administrative of the heritage buildings should play their roles accordingly with considering the right criteria that were highlighted by the experts. 


\subsection{Conclusion}

In conclusion, this paper reviewed some of the selected research on the fire safety management system for the heritage buildings in Malaysia that been carried which has proven that the level of the fire safety management system at heritage buildings in Malaysia is still at the low level. The application of the fire safety equipment is still lacking or improper and not up to the legislative requirement or satisfied condition. The fire safety system in the heritage buildings is mostly not been changed starting from the conservation process been made to the buildings, where some of them are not suitable to the new function of the buildings after undergoes an adaptive reuse. Most of the findings from the research stated that management team of the case studies or heritage buildings failed to implement a good fire safety planning or develop a proper fire safety management system in respective buildings. This is the most critical part of the fire safety management system of the heritage building in Malaysia which needs to be improved since there are also studies or research that been made proved that the most important attributes influence in reducing the risk of fire are fire safety management and the system itself.

From the findings of all selected researches also prove that occupants of the heritage buildings in Malaysia are aware of fire safety management system but they are not being able to react properly with all of the fire safety types of equipment in the buildings if there are fire occurs; since the exposure from the management department or team are less. Most of the occupants or respondents in the study stated that each of the heritage buildings should be placed with an experienced safety officer to guide or handle all the fire safety matters and also agreed that the management team should have a close connection to fire brigades in order to handle those things out according to the Fire \& Rescue Department Malaysia (FRDM). Besides, a proper installation or used of the fire protection and safety system in the heritage buildings can be achieved with this guidance in order to suit the new function of the buildings since it is also important aspects to be focused; the valuable building parts or materials or any things in the building that influenced the authenticity of the heritage buildings it selves. The objectives of having a proper fire safety management system not only to avoid any of fire occurrences but also to protect both of the occupants and heritage buildings itself, since the authenticity of the heritage buildings is depending on the buildings' part or material.

\section{Acknowledgements}

The authors like to thanks, University Teknologi MARA for funding this research under Bestari (32/2017) grant.

\section{References}

Akinciturk, N., \& Kilic, M. (2004). A study on the fire protection of historic Cumalikizik village. Journal of Cultural Heritage. https://doi.org/10.1016/j.culher.2004.01.001 Baker, J., Bouchlaghem, D., \& Emmitt, S. (2013). Categorisation of fire safety management: Results of a Delphi Panel. Fire Safety Journal. https://doi.org/10.1016/j.firesaf.2013.03.005

Bernardini, G., Azzolini, M., D'Orazio, M., \& Quagliarini, E. (2016). Intelligent evacuation guidance systems for improving the fire safety of Italian-style historical theatres without altering their architectural characteristics. Journal of Cultural Heritage. https://doi.org/10.1016/j.culher.2016.06.008

Chen, Y. Y., Chuang, Y. J., Huang, C. H., Lin, C. Y., \& Chien, S. W. (2012). The adoption of fire safety management for upgrading the fire safety level of existing hotel buildings. Building and Environment. https://doi.org/10.1016/j.buildenv.2011.12.001

Ibrahim, M. N., Abdul-Hamid, K., Ibrahim, M. S., Mohd-Din, A., Yunus, R. M., \& Yahya, M. R. (2011). The development of fire risk assessment method for the heritage building. In Procedia Engineering. https://doi.org/10.1016/j.proeng.2011.11.172

Ibrahim, M. N., Ibrahim, M. S., Mohd-Din, A., Abdul-Hamid, K., Yunus, R. M., \& Yahya, M. R. (2011). Fire risk assessment of heritage building - Perspectives of regulatory authority, restorer and building stakeholder. In Procedia Engineering. https://doi.org/10.1016/j.proeng.2011.11.173

Jamil, M. H. (2017). Fire Safety Management in Heritage Buildings.

Kidd, S. (2003). Risk Improvement in Historic and Heritage Buildings The threat to heritage buildings and their contents Fire spread in historic buildings and adaptive reuse.

Malhotra, H. L (1991). Fire Science \& Technology: Framework for a CIB Guide on Fire Safety for Historic Buildings. Vol.11, No.1, 2, 1991.

Marchant, E. W. (n.d.). Preventing Fire in Historic Buildings : The Acceptable Risk, (May 1989), 1988-1989.

Marrion, C. E. (2016). More effectively addressing fire/disaster challenges to protect our cultural heritage. Journal of Cultural Heritage. https://doi.org/10.1016/j.culher.2016.03.013

Meacham, B. J. (1999). Integrating human behaviour and response issues into fire safety management of facilities. Facilities, $17(9 / 10)$, 303-312. https://doi.org/10.1108/02632779910278719

Mohamad, W. M. A. W. (2015). The Importance of Fire Safety in Historic Buildings.

Mydin, M. A. O., Sani, N., Abas, N. F., \& Khaw, Y. Y. (2014). Evaluation of Fire Hazard and Safety Management of Heritage Buildings in Georgetown, Penang, 3. 
Mydin, M. A. O., \& Yen, K. Y. (2014). A Path toward Safer Heritage Buildings through Excellent Fire Prevention and Control System in Malaysia. Analele Universitatii $\begin{array}{lll}\text { "Eftimie } \quad \text { Murgu," 21(1), 231-242. } & \end{array}$ Retrieved

http://ezaccess.library.uitm.edu.my/login?url=http://search.ebscohost.com/login.aspx?direct=true\&db=aph\&AN=118950229\&site=ehost-live\&scope=site

Naziris, I. A., Lagaros, N. D., \& Papaioannou, K. (2016). Optimized fire protection of cultural heritage structures based on the analytic hierarchy process. Journal of Building Engineering. https://doi.org/10.1016/j.jobe.2016.08.007

Pickard, R. (1994). Fire Safety and Protection in Historic Buildings in England and Ireland - Part I. Structural Survey, 27-31. https://doi.org/10.1108/02630809410055692

Ramachandran, G. (1999). Fire safety management and risk assessment. Facilities, 17(9/10), 363-377. https://doi.org/10.1108/02632779910278782

Salleh, N. H., \& Ahmad, A. G. (2009), Fire Safety Management In Heritage Buildings : The Current Scenario In Malaysia.

Science, A. F. (2009). Recent Progress in Research of Fire Protection on Historic Buildings, (January). https://doi.org/10.2190/AF.19.1.d

Wang, G., Barber, D., Johnson, P., \& Hui, M. C. (2013). Fire safety provisions for aged concrete building structures. In Procedia Engineering. https://doi.org/10.1016/j.proeng.2013.08.108 